\title{
Comparison of transcriptional profiles of interferons, CXCL10 and RIG-1 in influenza infected A549 cells stimulated with exogenous interferons
}

\author{
V. LACHOVÁ ${ }^{1}$, L. ŠKORVANOVÁ ${ }^{1}$, D. SVETLÍKOVÁ ${ }^{1}$, L. TURIANOVÁ ${ }^{1}$, A. KOSTRÁBOVÁ ${ }^{2}$, T. BETÁKOVÁ ${ }^{1,2^{*}}$
}

${ }^{1}$ Institute of Virology, Biomedical Research Center Slovak Academy of Sciences, Dúbravská cesta 9, 84505 Bratislava, Slovak Republic; ${ }^{2}$ Comenius University in Bratislava, Department of Microbiology and Virology, Bratislava, Slovak Republic

Received August 8, 2016; revised September 30, 2016; accepted March 27, 2017

\begin{abstract}
Summary. - Type I and type III interferons (IFNs) are induced by viral infection. It was concluded that these IFN species are identical in regulation and biological functions. However, these two systems differ in the tissue expression of their receptors and their transcriptional regulation is fundamentally different as well as cellular signaling pathways that drive expression of each IFN. Here, we have investigated the transcriptional profile of endogenous IFNs after stimulation of cells with exogenous IFNs and subsequent infection of A549 cells with A/chicken/Germany/27 [H7N7] influenza virus. Both type I and type III IFNs exhibit high degree of the cross-induction. Our results show that type III IFNs (IFN- $\lambda 1$, IFN- $\lambda 2$ and IFN- $\lambda 3$ ) are better inducers of CXCL10 than type I IFNs. The IFN- $\beta 1$ a and IFN- $\lambda 2$ were the most potent IFNs and they highly increased the level of IFN- $\alpha$, IFN- $\beta$, IFN- $\lambda$, and CXCL10 mRNAs. Since type I IFNs up regulated expression of retinoic acid-inducible gene 1 (RIG-1) mRNA, type III IFNs- $\lambda$ down regulated expression of RIG-1 mRNA in influenza infected cells. IFN- $\alpha$ and IFN- $\omega$ induced similar amount of IFN- $\alpha$, IFN- $\beta$ and IFN- $\lambda$ mRNA but differ in induction of CXCL10 and RIG-1 mRNA.
\end{abstract}

Keywords: influenza virus; interferon; CXCL10; RIG-1; mRNA

\section{Introduction}

The interferon system represents one of the first line defences against influenza virus infection. IFNs represent a family of cytokines that are involved in several cellular functions. Type I interferon family consists of 13 IFN- $\alpha$ subtypes, IFN- $\beta$, IFN- $\omega$, and IFN- $\varepsilon$ (Cohen and Parker, 2016). Type II family is represented by IFN- $\gamma$ and type III IFN family consists of IFN- $\lambda 1$, IFN- $\lambda 2$, IFN- $\lambda 3$, and IFN- $\lambda 4$ (Sheppard et al., 2003; Kotenko et al., 2003; Uzé et al., 2007; Prokunina-Olsson et al., 2013). Single nucleotide polymorphism in the majority of the human population results in a frameshift mutation inhibiting IFN- $\lambda 4$ production (Hamming et al., 2013). There is $96 \%$ sequence identity between

*E-mail: virubeta@savba.sk ; phone: +421-2-59302-440. Abbreviations: IFN(s) = interferon(s); RIG-1 = retinoic acidinducible gene 1
IFN- $\lambda 2$ and IFN- $\lambda 3$ and approximately $81 \%$ sequence homology between IFN- $\lambda 1$ and IFN- $\lambda 2 / 3$ (Sheppard et al., 2003; Kotenko et al., 2003).

IFNs are associated with innate immunity and induce anti-proliferative and anti-inflammatory responses and are involved also in adaptive immune responses (Alexopoulou et al., 2001; Au et al., 2001; Pestka et al., 2004; Lopušná et al., 2013). Type I IFNs receptor complex consists of two chains, IFN-aR1 and IFN-aR2 (Uze et al., 1990; Cleary et al., 1994). Type III IFNs are structurally different from type I IFNs and bind to a distinct heterodimeric receptor containing unique IFN- $\lambda$ R1 and IL10R2 chains. The IL10R2 chain is also the second subunit of the receptor complexes for IL-10, IL-22, and IL-26 (Kotenko et al., 2003; Sheppard et al., 2003; Kotenko and Langer, 2004). Type III IFNs are induced in response to viral and bacterial stimuli, with almost complete overlap with the type I IFN pathway (Ank et al., 2008; Durbin et al., 2013). Binding of IFN- $\lambda$ to its receptor dimer induces JAK-STAT signaling similar to type I IFN signaling, result- 
ing in expression of over 300 interferon responsible genes (Dumoutier et al., 2004; Doyle et al., 2006; Cohen and Prince, 2013). While the type I and type III pathways activate a very similar gene set, there are significant differences between the pathways (Cohen and Parker, 2016). The expression of IFN $\lambda$ - $\mathrm{R}$ is restricted to a subset of cells, primarily epithelial cells, keratinocytes, some dendritic cells and neutrophil population (Sommereyns et al., 2008; Cohen and Prince, 2013; Blazek et al., 2015; Lukacikova et al., 2015; Mahlakõiv et al., 2015). Type I IFNs induce a more rapid and higher magnitude response compared to type III IFN, while type III IFNs induce a more sustained response of gene induction (Zhou et al., 2007; Bolen et al., 2014; Jilg et al., 2014).

The type I IFNs are usually represented by IFN- $\alpha$ in most studies concerning immune response against influenza virus. Here, we have compared anti-influenza activities of individual type I (IFN- $\alpha$, IFN- $\beta$, and IFN- $\omega$ ) and type III (IFN- $\lambda 1$, IFN- $\lambda 2$, and IFN- $\lambda 3$ ) IFNs and their abilities to induce IFN- $\alpha$, IFN- $\beta$, IFN- $\lambda$, CXCL10, and RIG-1 mRNAs. Our data show that final inhibitory effect cannot be assigned only to interferon which was used for induction of A549 cells prior infection. Both type I and type III IFNs exhibit high degree of the cross-induction and several fold increase in the level of CXCL10 transcript. Amount of RIG-1 mRNA was elevated by the type I IFN and downregulated by the type III IFNs. Despite the use of different receptor for type I and type III IFNs, both types of interferon resulted in predominant activation of IFN- $\beta$.

\section{Materials and Methods}

Cells and viruses. A549 (ATCC CCL 185) cells were grown in Dulbecco modified Eagle medium (DMEM) containing 10\% fetal calf serum (FCS). Influenza virus A/chicken/Germany/27 [H7N7] (kindly provided by Dr. AJ Hay, NIMR, London, UK) was cultured in 10 days old fertile hen's eggs.

Antiviral activity assay. Confluent monolayer of A549 cells (in 24 -well plates) was pre-incubated for $24 \mathrm{~h}$ with $0,10,20$, and 40 $\mathrm{ng} / \mathrm{ml}$ of recombinant human IL-29/IFN-lambda 1, recombinant human IL-28A/IFN-lambda 2, recombinant human IL-28B/IFNlambda 3, recombinant human IFN- $\omega$ (R\&D System, USA) or $0 \mathrm{U}$, $50 \mathrm{U}, 100 \mathrm{U}, 200 \mathrm{U}, 400 \mathrm{U}$, and $800 \mathrm{U}$ of recombinant human IFN- $\alpha$ $2 \mathrm{~b}$, recombinant human IFN- $\beta$ 1a (R\&D System). The cells were washed once with phosphate buffered saline (PBS) and then infected with influenza A/chicken/Germany/27 [H7N7] virus at a multiplicity of infection (MOI) of 0.5 plaque forming units per cell for $1 \mathrm{~h}$ at room temperature. After adsorption, cells were washed three times with PBS and then cultured in serum-free MEM at $37^{\circ} \mathrm{C}$. At $16 \mathrm{~h}$ post-infection, cells were scraped and centrifuged at $500 \times \mathrm{g}$ for 2 min. The viral titers in supernatants were determined on MDCK cells by plaque assay as described by Svetlikova et al. (2010).

Quantitative RT-PCR. Interferons, CXCL10, and RIG-1 mRNAs were quantified by semi-quanitative RT-PCR as previously described
(Svancarova et al., 2015b). Briefly, RNA from IFN pre-incubated and infected cells were extracted using the SV Total RNA isolation system (Promega, USA). RNA yields were evaluated by spectrophotometer at $260 \mathrm{~nm}$. Four hundred ng of RNA were reverse transcribed using random hexa-nucleotide primers and murine leukemia virus (MuLV) reverse transcriptase (Thermo Fisher Scientific, USA). To determine mRNA levels of IFN- $\alpha$, IFN- $\beta$, CXCL10, IFN- $\lambda$, RIG- 1 , and $\beta$-actin, RT-PCR was performed. The primers targeting $\beta$-actin, IFN- $\beta$ and IP 10 (precursor IFN- $\gamma$ ) were described previously (Varga et al., 2011; Zhang et al., 2014). The sequences of the primers were as follows: 5'-CTT GGG ATG AGA CCC TCC TAG AC-3' (forward) and 5'-GCA CAA GGG CTG TAT TTC TTC TC-3' (reverse) for IFN- $\alpha$ universal for subtypes 1 and 2; 5'-CTG ACG CTG AAG GTT CTG GAG-3' (forward) and 5'-AAT TCA GGT CTC GCG TGA GGA GGC-3' (reverse) for IFN- $\lambda 2$ and 3 ; 5 '-TGC AGT CAC GTC TTA TGT GAT AG-3' (forward) and 5'-CTC CCA CTG CTC GAA CCA GAA AC-3' (reverse) for RIG-1. The intensity of the obtained PCR bands was determined by using Gene Tools image analysis software.

Statistical evaluation. Each sample was analyzed in duplicate and repeated twice or more if the variation was more than $10 \%$. Significant differences in the virus titer between the control group (untreated cells) and IFNs pre-incubated cells were calculated using the unpaired Student's $t$-test. P values $<0.05$ were considered significant. The fold change ratios between control and experimental samples for each gene were calculated and normalized against $\beta$-actin. Statistical analysis was performed using Graph-Pad Prism software (http://www.graphpad.com/quickcalcs/ttest1.cfm).

\section{Results}

Virus A/chicken/Germany/27 [H7N7] is most inhibited in the cells pre-incubated with IFN- $\beta 1 a$ and IFN- $\omega$

Inhibition activity of IFNs was tested with avian strain [H7N7]. A549 cells were stimulated with different concentration of IFNs as described in material and methods. Subsequently, cells were infected with A/chicken/Gemany/27 [H7N7] virus and infected cells were scraped $24 \mathrm{~h}$ later and virus titer was determined. The concentration of IFN- $\alpha 2 b$, IFN- $\beta 1 a$, IFN- $\omega$, or IFNs- $\lambda$ with highest inhibitory effect was consider as an optimal concentration and all further experiments were performed with $400 \mathrm{U}$ of IFN- $a 2 \mathrm{~b}$ or IFN$\beta 1 \mathrm{a}, 10 \mathrm{ng} / \mathrm{ml}$ of IFN- $\omega$ or IFN- $\lambda 1$, and $20 \mathrm{ng} / \mathrm{ml}$ of IFN- $\lambda 2$ or IFN- $\lambda 3$. The best inhibitory activity was observed with IFN- $\omega$ and IFN- $\beta 1$ a. The virus titer was reduced to $17 \%$ (Fig.1). IFN- $\alpha 2$ b decreased the virus titer to $58 \%$ and IFN- $\lambda$ s inhibited virus replication up to $63 \%$.

\section{IFN- $\alpha$ mRNA was induced only by IFN- $\beta$}

To investigate the transcriptional profile of endogenous IFNs after stimulation of cells with exogenous type I and 


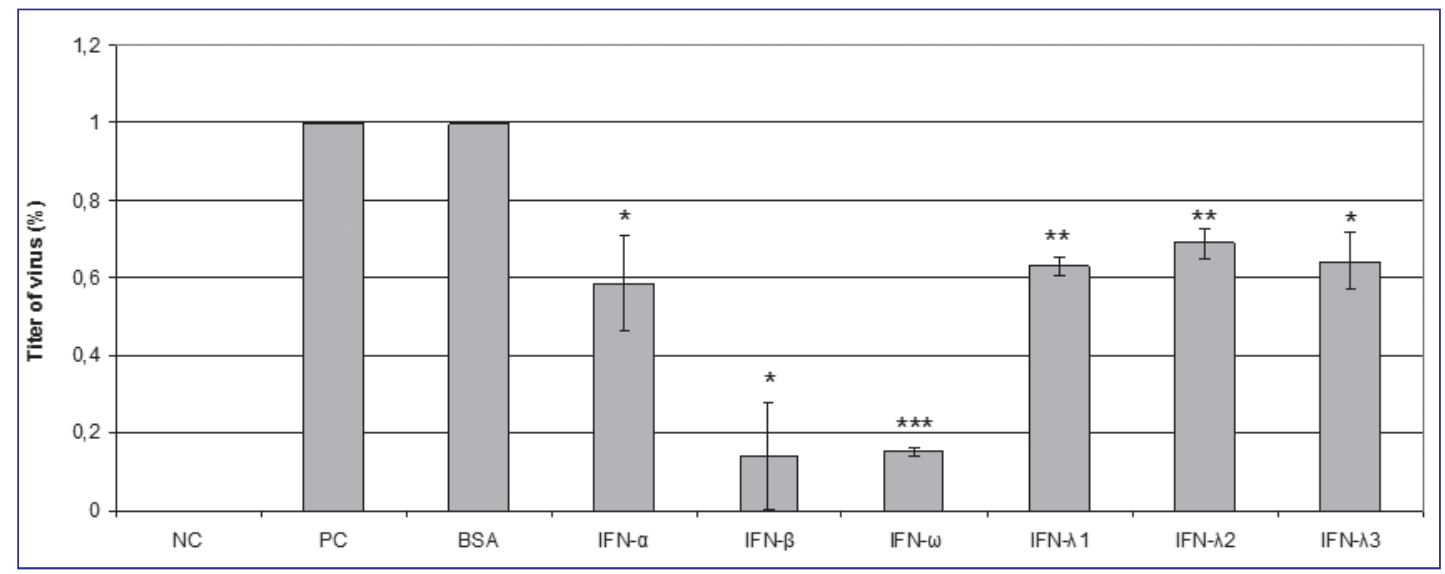

Fig. 1

Antiviral activity of IFN- $\alpha 2$, IFN- $\beta 1 \mathrm{a}$, IFN- $\omega$, IFN- $\lambda 1$, IFN- $\lambda 2$, and IFN- $\lambda 3$ in induced A549 cells infected with A/chicken/Germany/27 [H7N7] The column bars represent the average results with standard deviation from three experiments performed on different occasions. $100 \%$ represents infected cells without IFN. $400 \mathrm{U}$ of IFN- $\alpha 2$ and IFN- $\beta 1$ a were used. IFN- $\omega$ and IFN- $\lambda 1$ were used in concentration $10 \mathrm{ng} / \mathrm{ml}$ and IFN- $\lambda 2$ and IFN- $\lambda 3$ were used in concentration $20 \mathrm{ng} / \mathrm{ml}$. ${ }^{\star}$ Statistical significance $\left({ }^{\star} \mathrm{P}<0.05 ;{ }^{* *} \mathrm{P}<0.02 ;{ }^{* *} \mathrm{P}<0.01\right.$ by unpaired Student's $t$-test).

type III IFNs and subsequent infection of cells with influenza virus, we performed semi-quantitative RT-PCR. The level of IFN-a mRNA was insignificantly increased in the A549 cells after infection with influenza H7N7 virus. We assumed, that IFN- $\alpha$ will be the most potent to induce expression of IFN- $\alpha$ mRNA. However, induction of A549 cells with IFN- $\alpha$ and as well as with IFN- $\omega$ and IFNs- $\lambda$ did not result in the alteration of IFN- $\alpha$ mRNA expression in infected cells (Fig. 2). The level of IFN- $\alpha$ mRNA was significantly increased only in the A549 cells preincubated with IFN- $\beta$.
Induction of IFN- $\beta$ and IFN- $\lambda$ mRNA by type I and type III IFNs

In order to examine the induction capacity of individual IFNs, we analyzed the transcription level of mRNA IFN- $\beta$ and IFN- $\lambda$. Among all tested IFNs, IFN- $\beta 1$ a appeared to be the most potent and IFN- $\lambda 2$ induced expression of IFN- $\beta$ mRNA to comparable level, approximately 1.5 times (Fig. 3). While IFN- $\beta$ duplicated the production of IFN- $\lambda$ mRNA, IFNs- $\lambda$ significantly increased expression of its own

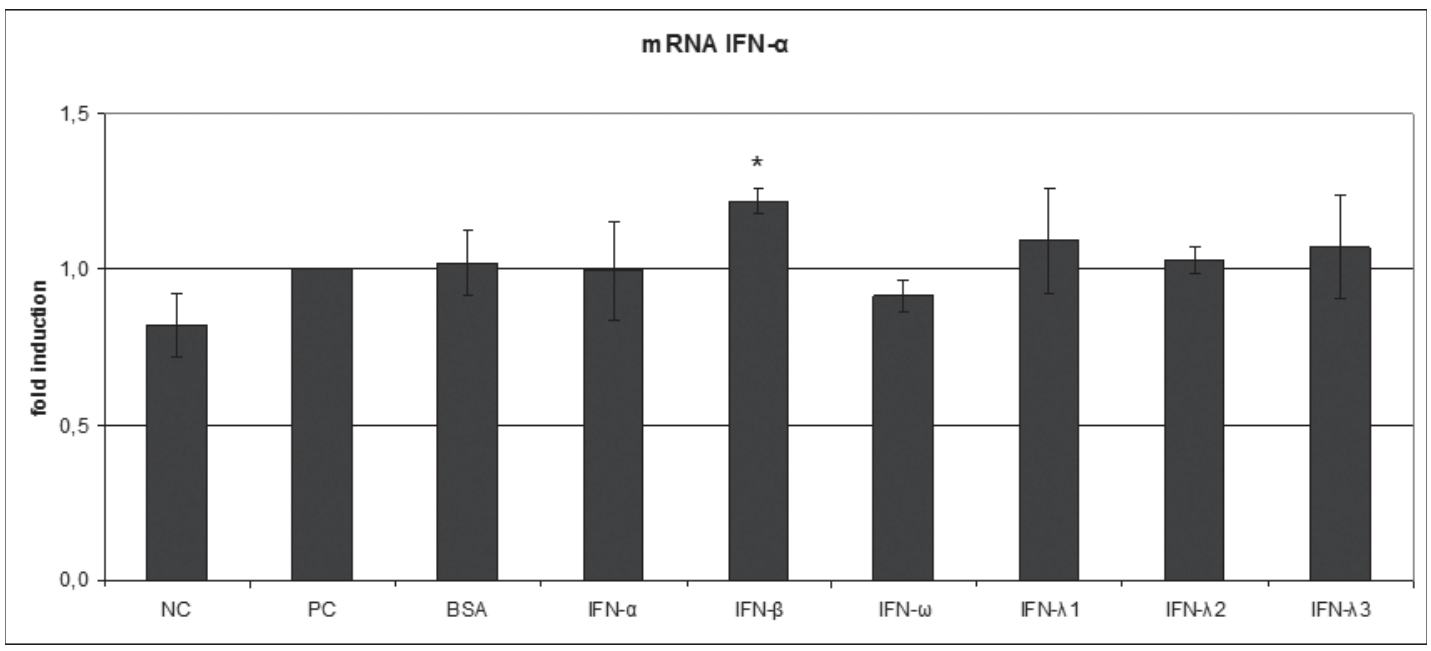

Fig. 2

Quantitative RT-PCR analysis of IFN- $\alpha$ mRNA in A549 cells

A549 cells were induced with IFNs and infected with influenza virus. NC-A549 cells, PC-A549 cells infected with influenza virus, BSA-A549 cells preincubated with $20 \mathrm{ng} / \mathrm{ml} \mathrm{BSA}$ and then infected with influenza virus. The column bars represent the average results with standard deviation from three experiments performed on different occasions. ${ }^{*}$ Statistical significance $\left({ }^{*} \mathrm{P}<0.05 ;{ }^{* *} \mathrm{P}<0.02 ;{ }^{* *} \mathrm{P}<0.01\right.$ by unpaired Student's $t$-test). 
mRNA, but only 1.3 times (Fig. 4). The activity of IFN- $a$ and IFN- $\omega$ was very similar and both IFNs induced expression of either IFN- $\beta$ mRNA or IFN- $\lambda$ mRNA approximately 1.2 time (Fig. 3 and 4). In conclusion, both type I and type III IFNs exhibit high degree of the cross-induction of IFN- $\beta$ and IFN- $\lambda$ mRNAs.
Type I and type III IFNs stimulate expression of CXCL10 $m R N A$

The binding of type I and type II IFNs to their receptors induces signaling cascades that result in the activation of STAT1 and STAT2. We wanted to examine the induction of CXCL10

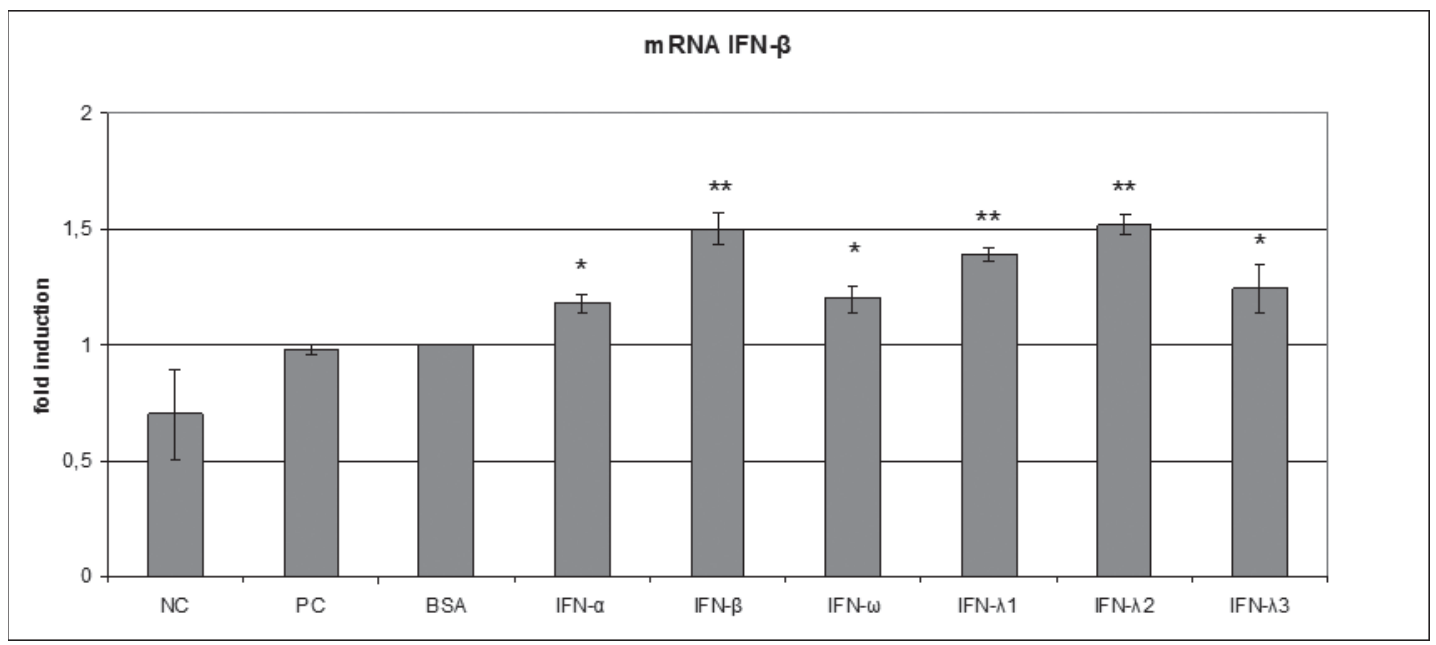

Fig. 3

Quantitative RT-PCR analysis of IFN- $\beta$ mRNA in A549 cells

A549 cells were induced with IFNs and infected with influenza virus. NC-A549 cells, PC-A549 cells infected with influenza virus, BSA-A549 cells preincubated with $20 \mathrm{ng} / \mathrm{ml} \mathrm{BSA}$ and then infected with influenza virus. The column bars represent the average results with standard deviation from three experiments performed on different occasions. ${ }^{\star}$ Statistical significance $\left({ }^{*} \mathrm{P}<0.05 ;{ }^{*} \mathrm{P}<0.02 ;{ }^{* *} \mathrm{P}<0.01\right.$ by unpaired Student's $t$-test).

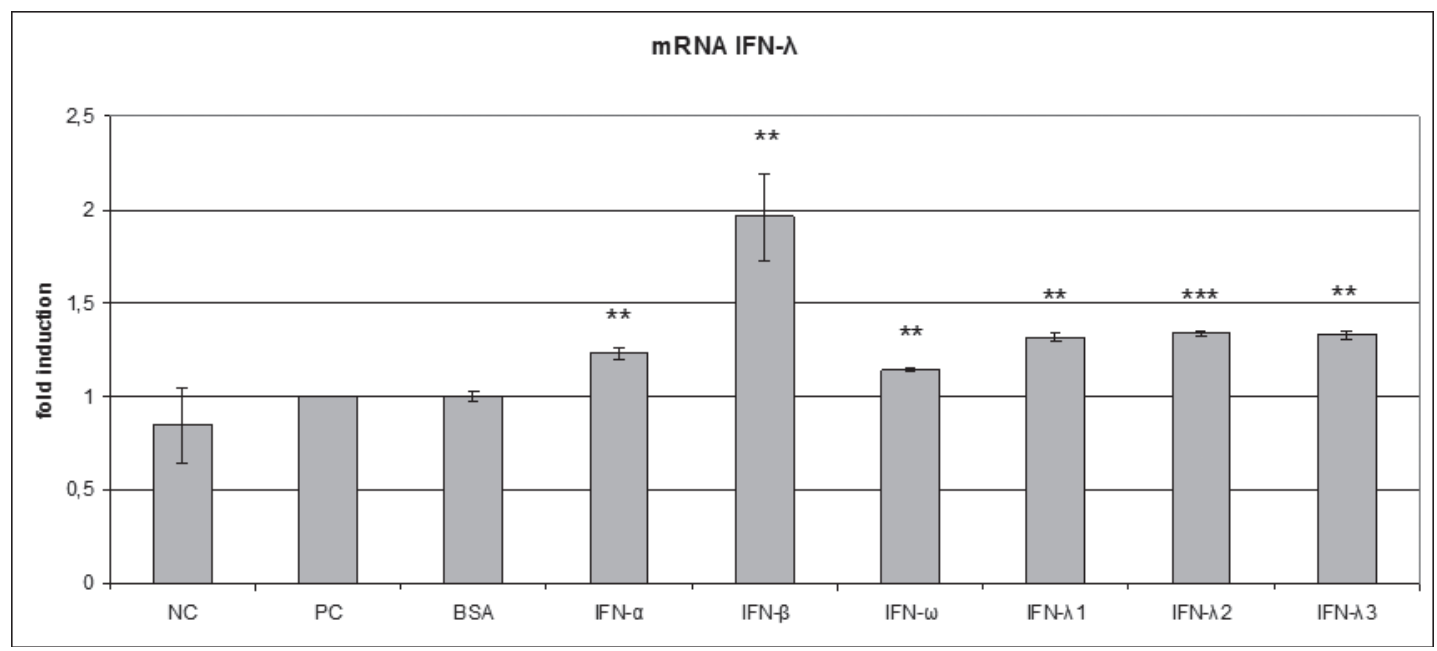

Fig. 4

Quantitative RT-PCR analysis of IFN- $\lambda$ mRNA in A549 cells

A549 cells were induced with IFNs and infected with influenza. NC-A549 cells, PC-A549 cells infected with influenza virus, BSA- A549 cells pre-incubated with $20 \mathrm{ng} / \mathrm{ml}$ BSA and then infected with influenza virus. The column bars represent the average results with standard deviation from three experiments performed on different occasions. ${ }^{\star}$ Statistical significance $\left({ }^{*} \mathrm{P}<0.05 ;{ }^{* *} \mathrm{P}<0.02 ;{ }^{* \star} \mathrm{P}<0.01\right.$ by unpaired Student's $t$-test). 
and see whether type I and type III IFNs can cross-induce also the type II IFN pathway. Influenza virus induced expression of CXCL10 mRNA in infected cells. The expression of CXCL10 mRNA was several folds more upregulated in the A549 cells induced with IFNs. The type I IFNs, especially IFN- $\beta$ increased expression of CXCL10 mRNA more than 6 times, while IFN- $\omega$ and IFN- $\alpha$ increased its expression 4 or 2.4 times, respectively (Fig. 5). The IFN- $\lambda 1$ was lower than that of IFNs- $\lambda 2 / 3$, which was comparable to activity of IFN- $\beta$.
The type I IFNs upregulated and the type III IFNs downregulated expression of RIG-1 $\mathrm{mRNA}$ in influenza infected cells

Gene expressions of RIG-1 in induced A549 cells were also studied. Infection of A549 cells with H7N7 virus did not influence the level of RIG-1 mRNA (Fig. 6). While, the IFNs- $\alpha / \beta$ induced the level of RIG-1 mRNA 1.7 times, the IFN- $\omega$ exhibited lesser activity and induced RIG-1 mRNA

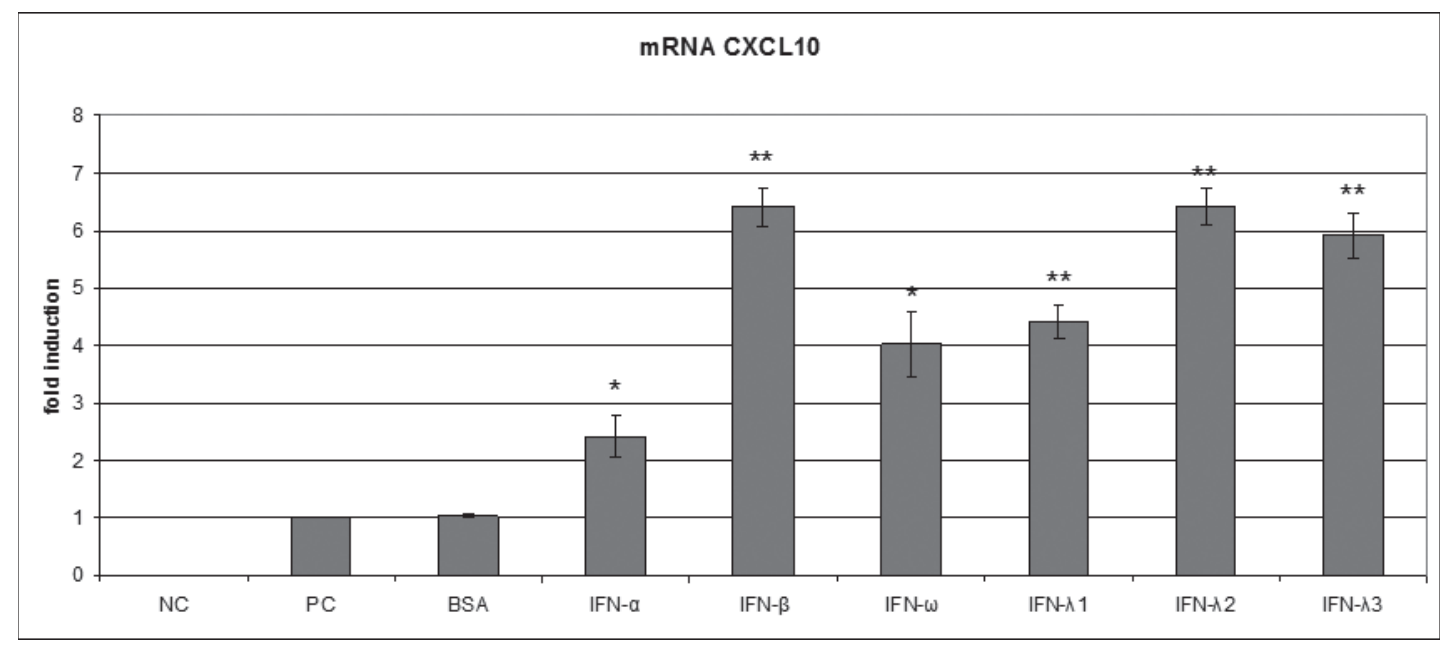

Fig. 5

Quantitative RT-PCR analysis of CXCL10 mRNA in A549 cells

A549 cells were induced with IFNs and infected with influenza virus. NC-A549 cells, PC-A549 cells infected with influenza virus, BSA-A549 cells preincubated with $20 \mathrm{ng} / \mathrm{ml} \mathrm{BSA}$ and then infected with influenza virus. The column bars represent the average results with standard deviation from three experiments performed on different occasions. ${ }^{*}$ Statistical significance $\left({ }^{*} \mathrm{P}<0.05 ;{ }^{* *} \mathrm{P}<0.02 ;{ }^{* *} \mathrm{P}<0.01\right.$ by unpaired Student's $t$-test).

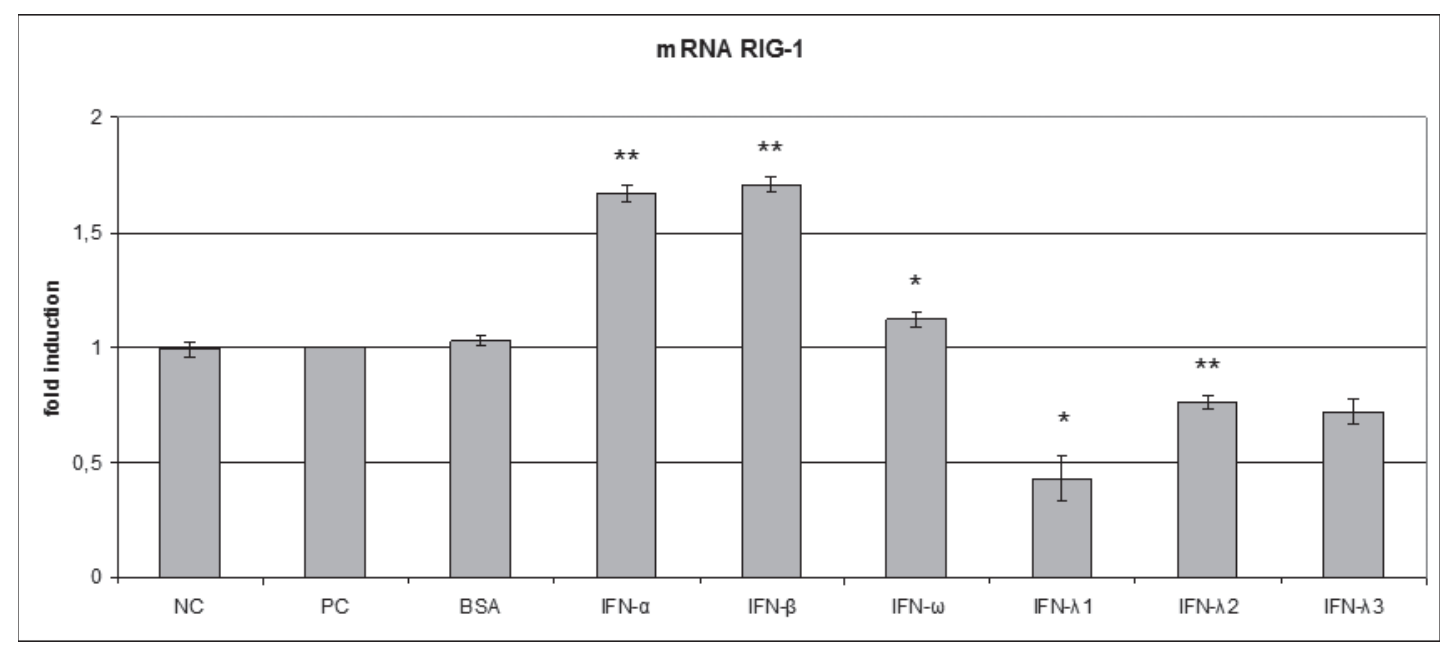

Fig. 6

Quantitative RT-PCR analysis of RIG-1 mRNA in A549 cells

A549 cells were induced with IFNs and infected with influenza virus. NC-A549 cells, PC-A549 cells infected with influenza virus, BSA-A549 cells preincubated with $20 \mathrm{ng} / \mathrm{ml} \mathrm{BSA}$ and then infected with influenza virus. The column bars represent the average results with standard deviation from three experiments performed on different occasions. ${ }^{\star}$ Statistical significance $\left({ }^{\star} \mathrm{P}<0.05 ;{ }^{* *} \mathrm{P}<0.02 ;{ }^{* *} \mathrm{P}<0.01\right.$ by unpaired Student's $t$-test). 
only 1.12 times. On the other hand, the activity of IFN- $\lambda 2$ and IFN- $\lambda 3$ was indistinguishable and both IFNs reduced the production of RIG-1 mRNA 0.72 times. Induction of A549 cells with IFN- $\lambda 1$ resulted in more than half decrease in RIG-1 mRNA production. In conclusion, the type I IFNs upregulated and the type III IFNs downregulated expression of RIG-1 mRNA in infected cells.

\section{Discussion}

Most viruses are able to induce production of IFNs (Biron, 1999; Kotenko et al., 2003; Coccia et al., 2004; Mihm et al., 2004; Svetlikova et al., 2010). It was already proved, that the type I IFN can stimulate production of the type III IFN and vice versa. They differ in receptor composition but they stimulate the same JAK/STAT pathways and induce a similar repertoire of genes (Zhou et al., 2007; Cohen and Parker, 2016). Type I and type III IFNs are differentially regulated at the transcription level.

Anti-virus activity of IFN is generally assigned to the interferon which was used for induction of cells or for treatment of experimental animals. We were interested in comparing the activity of IFN- $\alpha 2 b$ with activity of IFN- $\beta 1$ a or IFN- $\omega$. Primary sequence comparison between the IFN $\alpha$ and $\beta$ subtypes reveal an approximately $50 \%$ amino acid homology (Pestka et al., 1987). Human IFN- $\omega$ is antigenetically different from human IFN- $\alpha$ and IFN- $\beta$ and has $65 \%$ amino acid sequence homology and similar function as IFN- $\alpha$ (Adolf, 1987). IFN- $\beta$, but not IFN- $\alpha$, induces the association of tyrosine-phosphorylated receptor components IFNaR1 and IFNaR2, and has activity in cells lacking the IFN receptor-associated, Janus kinase TYK2 (Runkel et al., 1998). Previous studies have shown the protective potential of human exogenous IFN- $\omega$ against influenza viruses (Xu et al., 2011; Skorvanova et al., 2015). The activities of individual type I IFNs differ from each other. The IFN- $\beta 1$ a was the only interferon which induced level of IFN- $\alpha$ mRNA. The IFN$\alpha 2 b$ and IFN- $\omega$ activate similar amount of IFN- $\beta$ and IFN- $\lambda$ mRNA but they differ in activation of CXCL10 and RIG-1 mRNA. Thus IFN- $\omega$ may be a useful and alternative antiviral agent, in addition to IFN- $\alpha$ and IFN- $\beta$. The highest potency for induction of IFN- $\alpha$, IFN- $\beta$, IFN- $\lambda$, CXCL10 and RIG-1 mRNA was manifested by the IFN- $\beta 1$ a. All IFN- $\lambda$ stimulated the expression of IFN- $\beta$, IFN- $\lambda$ and CXCL10 mRNA but did not influence level of IFN- $\alpha$ mRNA and downregulated RIG-1 mRNA.

RIG-1 can be induced by influenza virus infection (Gao et al., 2012). However, the influenza virus NS1 protein can antagonize RIG-1 signaling and suppress its function (Pichlmair et al., 2006; Mibayashi et al., 2007). Previous studies show, that type III IFNs are produced at significantly higher level than type I IFNs in response to influenza virus without inducing expression of RIG-1 (Jewell et al., 2010; Svancarova et al., 2015a). Avian influenza virus did not induce expression of RIG-1 in A549 cells. The level of RIG-1 mRNA was significantly increased only in the infected cells pre-incubated with type I IFNs. This finding just proves that type I and type III IFNs are differentially regulated. Type I IFNs are induced by the combined action of the transcription factor AP-1, interferon regulatory factor (IRF) 3, IRF7, and NFKB (Thanos and Maniatis, 1995). However, only IRF3, IRF7, and $\mathrm{NF} \kappa \mathrm{B}$ are required for type III IFN production (Odendall $e t$ al., 2014). The IFNs induction is dependent on the JNK1/2 signaling pathway and induction of the RIG-1 is dependent on the ERK1/2 or JNK1/2 pathways (Ludwig et al., 2001; Gao et al., 2012).

All tested IFNs highly increased level of CXCL10 mRNA. CXCL10 cytokine, formerly known as IFN- $\gamma$-inducible protein 10 (IP-10) plays critical roles in enhancing the recruitment and activation of Th1 and Tc cells (Padovan et al., 2002; Villarroel et al., 2014). Expression of CXCL10 can be highly induced in a variety of cells by stimulation with type I and type II IFNs (Luster and Ravetch, 1987; Padovan et al., 2002). Our results show that type III IFNs induce expression of the CXCL10 and their induction ability is better than type I IFNs. Binding of IFN- $\gamma$ to its receptor (IFN- $\gamma$ R) activates the JAK-STAT pathway and leads to CXCL10 secretion. Positive regulator for CXCL10 transcription is NF- $\kappa \mathrm{B}$ (Helbig et al., 2009; Brownell et al., 2013; Liu et al., 2016). Since the type I and type III IFNs induce JAK-STAT pathways as well as expression of NF- $\kappa \mathrm{B}$, it is not surprising that overexpression of CXCL10 mRNA occurs.

It is obvious that the transcriptional regulation of type I and type III IFNs are fundamentally different as well as cellular signaling pathways that drive expression of each IFN. It is not possible to study type I IFNs pathway and ignore the type II and type III IFNs pathway. Due to the parallel nature of these pathways, action of individual IFNs could be enhanced or reduced. Better understanding of IFNs signaling is essential for understanding the biological activities of individual IFNs, avoiding the toxicities associated with IFNs and/or designing of novel therapeutics.

Acknowledgement. This research was supported by Slovak Research and Development Agency (Grant No. APVV-0676-12) and by the VEGA-Grant Agency of Science (Grant No. 2/0014/16).

\section{References}

Ank N, Iversen MB, Bartholdy C, Staeheli P, Hartmann R, Jensen UB, Dagnaes-Hansen F, Thomsen AR, Chen Z, Haugen H, Klucher K, Paludan SR (2008): An important role for type III interferon (IFN-lambda/IL-28) in TLR-induced antiviral activity. J. Immunol. 180, 2474-2485. https://doi. org/10.4049/jimmunol.180.4.2474 
Au WC, Yeow WS, Pitha PM (2001): Analysis of functional domains of interferon regulatory factor 7 and its association with IRF-3. Virology 280: 273-282. https://doi.org/10.1006/ viro.2000.0782

Biron CA (1999): Initial and innate responses to viral infectionspattern setting in immunity or disease. Curr. Opin. Microbiol. 2, 374-381. https://doi.org/10.1016/S13695274(99)80066-6

Blazek K, Eames HL, Weiss M, Byrne AJ, Perocheau D, Pease JE, Doyle S, McCann F, Williams RO, Udalova IA (2015): IFN- $\lambda$ resolves inflammation via suppression of neutrophil infiltration and IL-1 $\beta$ production. J. Exp. Med. 212, 845-853. https://doi.org/10.1084/jem.20140995

Bolen CR, Ding S, Robek MD, Kleinstein SH (2014): Dynamic expression profiling of type I and type III interferonstimulated hepatocytes reveals a stable hierarchy of gene expression. Hepatology 59, 1262-1272. https://doi. org/10.1002/hep. 26657

Brownell J, Wagoner J, Lovelace ES, Thirstrup D, Mohar I, Smith W, Giugliano S, Li K, Crispe IN, Rosen HR, Polyak SJ (2013): Independent, parallel pathways to CXCL10 induction in HCV- infected hepatocytes. J. Hepatol. 59,701-708. https://doi.org/10.1016/j.jhep.2013.06.001

Cleary CM, Donnelly RJ, Soh J, Mariano TM, Pestka S (1994): Knockout and reconstitution of a functional human type I interferon receptor complex. J. Biol. Chem. 269, 18747-18749.

Coccia EM, Severa M, Giacomini E, Monneron D, Remoli ME, Julkunen I, Cella M, Lande R, Uzé G (2004): Viral infection and Toll-like receptor agonists induce a differential expression of type I and lambda interferons in human plasmacytoid and monocyte-derived dendritic cells. Eur. J. Immunol. 34, 796-805. https://doi.org/10.1002/eji.200324610

Cohen TS, Parker D (2016): Microbial pathogenesis and type III interferons. Cytokine Growth Factor Rev. 29, 45-51. https://doi.org/10.1016/j.cytogfr.2016.02.005

Cohen TS, Prince AS (2013): Bacterial pathogens activate a common inflammatory pathway through IFN $\lambda$ regulation of PDCD4. PLoS Pathog. 9, e1003682. https://doi. org/10.1371/journal.ppat.1003682

Doyle SE, Schreckhise H, Khuu-Duong K, Henderson K, Rosler R, Storey H, Yao L, Liu H, Barahmand-pour F, Sivakumar P, Chan C, Birks C, Foster D, Clegg CH, Wietzke-Braun P, Mihm S, Klucher KM (2006): Interleukin-29 uses a type 1 interferon-like program to promote antiviral responses in human hepatocytes. Hepatology 44, 896-906. https:// doi.org/10.1002/hep. 21312

Durbin RK, Kotenko SV, Durbin JE (2013): Interferon induction and function at the mucosal surface. Immunol. Rev. 255, 25-39. https://doi.org/10.1111/imr.12101

Dumoutier L, Tounsi A, Michiels T, Sommereyns C, Kotenko SV, Renauld JC (2004): Role of the interleukin (IL)-28 receptor tyrosine residues for antiviral and antiproliferative activity of IL-29/interferon-lambda 1: similarities with type I interferon signaling J. Biol. Chem. 279, 32269-32274. https://doi.org/10.1074/jbc.M404789200

Gao W, Sun W, Qu B, Cardona CJ, Powell K, Wegner M, Shi Y, Xing Z (2012): Distinct regulation of host responses by ERK and JNK MAP kinases in swine macrophages infected with pandemic (H1N1) 2009 influenza virus. PLoS One 7, e30328. https://doi.org/10.1371/journal.pone.0030328

Hamming OJ, Terczyńska-Dyla E, Vieyres G, Dijkman R, Jørgensen SE, Akhtar H, Siupka P, Pietschmann T, Thiel V, Hartmann R (2013): Interferon lambda 4 signals via the IFN $\lambda$ receptor to regulate antiviral activity against $\mathrm{HCV}$ and coronaviruses. EMBO J. 32, 3055-3065. https://doi. org/10.1038/emboj.2013.232

Helbig KJ, Ruszkiewicz A, Lanford RE, Berzsenyi MD, Harley HA, McColl SR, Beard MR (2009): Differential expression of the CXCR3 ligands in chronic hepatitis $\mathrm{C}$ virus (HCV) infection and their modulation by HCV in vitro. J. Virol. 83, 836-846. https://doi.org/10.1128/JVI.01388-08

Jilg N, Lin W, Hong J, Schaefer EA, Wolski D, Meixong J, Goto K, Brisac C, Chusri P, Fusco DN, Chevaliez S, Luther J, Kumthip K, Urban TJ, Peng LF, Lauer GM, Chung RT (2014): Kinetic differences in the induction of interferon stimulated genes by interferon- $\alpha$ and interleukin $28 \mathrm{~B}$ are altered by infection with hepatitis $C$ virus. Hepatology 59 , 1250-1261. https://doi.org/10.1002/hep.26653

Jewell NA, Cline T, Mertz SE, Smirnov SV, Fla-o E, Schindler C, Grieves JL, Durbin RK, Kotenko SV, Durbin JE (2010): Lambda interferon is the predominant interferon induced by influenza A virus infection in vivo. J. Virol. 84, 11515-11522. https://doi.org/10.1128/JVI.01703-09

Kotenko SV, Gallagher G, Baurin VV, Lewis-Antes A, Shen M, Shah NK, Langer JA, Sheikh F, Dickensheets H, Donnelly RP. (2003): IFN-lambdas mediate antiviral protection through a distinct class II cytokine receptor complex. Nat. Immunol. 4, 69-77. https://doi.org/10.1038/ni875

Kotenko SV, Langer JA (2004): Full house: 12 receptors for 27 cytokines. Int. Immunopharmacol. 4, 593-608. https:// doi.org/10.1016/j.intimp.2004.01.003

Liu Y, Chen L, Zou Z, Zhu B, Hu Z, Zeng P, Wu L, Xiong J (2016): Hepatitis $C$ virus infection induces elevation of CXCL10 in human brain microvascular endothelial cells. J. Med. Virol. 88, 1596-603. https://doi.org/10.1002/jmv.24504

Lopušná K, Režuchová I, Betáková T, Škovranová L, Tomašková J, Lukáčiková L, Kabát P (2013): Interferons lambda, new cytokines with antiviral activity. Acta Virol. 57, 171-179. https://doi.org/10.4149/av 201302171

Ludwig S, Wang X, Ehrhardt C, Zheng H, Donelan N, Planz O, Pleschka S, García-Sastre A, Heins G, Wolff T (2002): The influenza A virus NS1 protein inhibits activation of Jun N-terminal kinase and AP-1 transcription factors. J. Virol. 76, 11166-11171. https://doi.org/10.1128/ JVI.76.21.11166-11171.2002

Lukacikova L, Oveckova I, Betakova T, Laposova K, Polcicova K, Pastorekova S, Pastorek J, Tomaskova J (2015): Antiviral effect of interferon lambda against lymphocytic choriomeningitis virus. J. Interferon Cytokine Res. 35, 540-553. https://doi.org/10.1089/jir.2014.0083

Luster AD, Ravetch JV (1987): Genomic characterization of a gamma-interferon-inducible gene (IP-10) and identification of an interferon-inducible hypersensitive site. Mol. Cell. Biol. 7, 3723-3731. https://doi.org/10.1128/ MCB.7.10.3723 
Mahlakõiv T, Hernandez P, Gronke K, Diefenbach A, Staeheli P (2015): Leukocyte-derived IFN- $\alpha / \beta$ and epithelial IFN- $\lambda$ constitute a compartmentalized mucosal defense system that restricts enteric virus infections. PLoS Pathog. 11, e1004782. https://doi.org/10.1371/journal.ppat.1004782

Mibayashi M, Martínez-Sobrido L, Loo YM, Cárdenas WB, Gale M Jr, García-Sastre A (2007): Inhibition of retinoic acidinducible gene I-mediated induction of beta interferon by the NS1 protein of influenza A virus. J. Virol. 81, 514-524 https://doi.org/10.1128/JVI.01265-06

Mihm S, Frese M, Meier V, Wietzke-Braun P, Scharf JG, Bartenschlager R, Ramadori G (2004): Interferon type I gene expression in chronic hepatitis C. Lab. Invest. 84, 11481159. https://doi.org/10.1038/labinvest.3700135

Odendall C, Dixit E, Stavru F, Bierne H, Franz KM, Durbin AF, Boulant S, Gehrke L, Cossart P, Kagan JC (2014): Diverse intracellular pathogens activate type III interferon expression from peroxisomes. Nat. Immunol. 15, 717-726. https://doi.org/10.1038/ni.2915

Padovan E, Spagnoli GC, Ferrantini M, Heberer M (2002): IFNalpha2a inducesIP-10/CXCL10 and MIG/CXCL9 production in monocyte-derived dendritic cells and enhances their capacity to attract and stimulate CD8+ effector T cells. J. Leukoc. Biol. 71, 669-676.

Pestka S, Langer JA, Zoon KC, Samuel CE (1987): Interferons and their actions. Annu. Rev. Biochem. 56, 727-777. https:// doi.org/10.1146/annurev.bi.56.070187.003455

Pestka S, Krause CD, Walter MR (2004): Interferons, interferon-like cytokines, and their receptors. Immunol. Rev. 202, 8-32. https://doi.org/10.1111/j.0105-2896.2004.00204.x

Pichlmair A, Schulz O, Tan CP, Näslund TI, Liljeström P, Weber F, Reis e Sousa C (2006): RIG-I-mediated antiviral responses to single-stranded RNA bearing 5'-phosphates. Science 314, 997-1001 https://doi.org/10.1126/science.1132998

Prokunina-Olsson L, Muchmore B, Tang W, Pfeiffer RM, Park H, Dickensheets H, Hergott D, Porter-Gill P, Mumy A, Kohaar I, Chen S, Brand N, Tarway M, Liu L, Sheikh F, Astemborski J, Bonkovsky HL, Edlin BR, Howell CD, Morgan TR, Thomas DL, Rehermann B, Donnelly RP, O'Brien TR (2013): A variant upstream of IFNL3 (IL28B) creating a new interferon gene IFNL4 is associated with impaired clearance of hepatitis C virus. Nat. Genet. 45, 164-171. https://doi.org/10.1038/ng.2521

Runkel L, Pfeffer L, Lewerenz M, Monneron D, Yang CH, Murti A, Pellegrini S, Goelz S, Uzé G, Mogensen K (1998): Differences in activity between alpha and beta type I interferons explored by mutational analysis. J. Biol. Chem. 273, 8003-8008. https://doi.org/10.1074/jbc.273.14.8003

Sheppard P, Kindsvogel W, Xu W et al. (2003): IL-28, IL-29 and their class II cytokine receptor IL-28R. Nat. Immunol. 4, 63-68. https://doi.org/10.1038/ni873

Škorvanová L, Švančarová P, Svetlíková D, Betáková T (2015): Protective efficacy of IFN- $\omega$ and IFN- $\lambda$ s against influenza viruses in induced A549 cells. Acta Virol. 59, 413-417. https://doi.org/10.4149/av_2015 $04 \_413$
Sommereyns C, Paul S, Staeheli P, Michiels T (2008): IFN-lambda (IFN-lambda) is expressed in a tissue-dependent fashion and primarily acts on epithelial cells in vivo. PLoS Pathog. 4, e1000017. https://doi.org/10.1371/journal. ppat. 1000017

Svancarova P, Svetlikova D, Betakova T (2015a): Induction of interferon lambda in influenza A virus infected cells treated with shRNAs against M1 transcript. Acta Virol. 59, 148-155. https://doi.org/10.4149/av 2015 $02 \quad 148$

Svancarova P, Svetlikova D, Betakova T (2015b): Synergic and antagonistic effect of small hairpin RNAs targeting the NS gene of the influenza A virus in cells and mice. Virus Res. 195, 100-111. https://doi.org/10.1016/j. virusres.2014.08.004

Svetlikova D, Kabat P, Ohradanova A, Pastorek J, Betakova T (2010): Influenza $A$ virus replication is inhibited in IFN- $\lambda 2$ and IFN- $\lambda 3$ transfected or stimulated cells. Antiviral Res. 88, 329-233. https://doi.org/10.1016/j.antiviral.2010.10.005

Thanos D, Maniatis T (1995): Virus induction of human IFN beta gene expression requires the assembly of an enhanceosome. Cell 83, 1091-100. https://doi.org/10.1016/00928674(95)90136-1

Varga ZT, Ramos I, Hai R, Schmolke M, García-Sastre A, Fernandez-Sesma A, Palese P (2011): The influenza virus protein PB1-F2 inhibits the induction of type I interferon at the level of the MAVS adaptor protein. PLoS Pathog 7, e1002067. https://doi.org/10.1371/journal.ppat.1002067

Villarroel VA, Okiyama N, Tsuji G, Linton JT, Katz SI (2014): CXCR3-mediated skin homing of autoreactive CD8 T cells is a key determinant in murine graft-versus-host disease. J. Invest. Dermatol. 134, 1552-1560. https://doi. org/10.1038/jid.2014.2

Uzé G, Lutfalla G, Gresser I (1990): Genetic transfer of a functional human interferon alpha receptor into mouse cells: cloning and expression of its cDNA. Cell 60, 225-234. https://doi. org/10.1016/0092-8674(90)90738-Z

Uzé G, Monneron D (2007): IL-28 and IL-29: newcomers to the interferon family. Biochimie 89, 729-734. https://doi. org/10.1016/j.biochi.2007.01.008

Xu C, Song X, Fu L, Dong D, Wu S, Li G, Yi S, Yu T, Yu R, Hou L, Chen W (2011): Antiviral potential of exogenous human omega interferon to inhibit pandemic 2009 A (H1N1) influenza virus. Viral Immunol. 24, 369-374. https://doi. org/10.1089/vim.2011.0003

Zhang S, Sun Y, Chen H, DaY Y, Zhang Y, Yu S, Qiu X, Tan L, Song C, Ding Ch (2014). Activation of the PKR/eIF2a signaling cascade inhibits replication of Newcastle disease virus, Virology J. 11, 62. https://doi.org/10.1186/1743422X-11-62

Zhou Z, Hamming OJ, Ank N, Paludan SR, Nielsen AL, Hartmann R (2007): Type III interferon (IFN) induces a type I IFN-like response in a restricted subset of cells through signaling pathways involving both the Jak-STAT pathway and the mitogen-activated protein kinases. J. Virol. 81, 7749-7758. https://doi.org/10.1128/JVI.02438-06 